\title{
Human Security
}

Human security refers to the protection of individual safety, dignity, and wellbeing at both the national and international level. While the notion of security has been historically mainly associated with state security and military threats, the concept of human security has broadened its meaning to include individuals as new referent objects and to envisage other kinds of threats (economic, environmental, health, political, etc.) to their safety. In the human security framework, individuals are not only put at the center of the attention, but also their safety is considered crucial for international peace and stability. Human security is understood beyond the physical safety or survival of individuals; it concerns people's physical and psychological integrity, dignity and well-being.

The concept emerged in 1990s, when the end of the Cold War radically altered the international security structure. The notion of human security was first conceptualized in the 1994 United Nations Development Program (UNDP), when the Human Development Report (UNDP 1994) provided a broad definition of the concept in terms of concern for human life and dignity. The term was officially framed in 2001 by the Commission on Human Security, which was established in response to the UN Secretary-General's call at the 2000 Millennium Summit for a world "free from want and fear." It was defined as follows: "Human security means protecting fundamental freedoms-freedoms that are the essence of life. It means protecting people from critical (severe) and pervasive (widespread) threats and situations. It means using processes that build on people's strengths and aspirations. It means creating political, social, environmental, economic, military and cultural systems that together give people the building blocks of survival, livelihood and dignity" (Ogata and Sen 2003).

In the humanitarian sector, the conceptualization of human security, understood in terms of rights rather than needs, has brought an increasing emphasis on protection activities and humanitarian actors' widespread shift from a needs-based approach to a rights-based approach to assistance. The protection of individuals' safety, dignity, and integrity has become a core element of assistance, along with the more traditional sectors of intervention such as food, water, shelter, and health.

More generally, by putting the human being at the center of the global security system, the elaboration of the notion of human security has had several important implications. The concept has been used to justify military 
humanitarian interventions considered necessary to address serious violations of people's human security during internal conflict or civil war, natural disasters, famine, and other emergencies. In order to protect human security, the international community can be called into action, not only by the aggressive behavior of one state towards another, but also by serious violations of human rights perpetrated against people by another non-state actor and/or the state itself.

Proponents of human security have underlined its potential emancipatory power in different realms - from the possibility to address economic, social, and political causes of human insecurity (Newman 2001) to the capacity of challenging existing power relations (Grayson 2004); from the claim that human security tends to be and is produced through individual empowerment (Tadjbakhsh and Chenoy 2007) to the potential of human security in giving voice to the voiceless and powerless (Suhrke 1999; MacFarlane 2004). Critical readings, however, have pointed out the inability of human security agendas to disrupt existing power inequalities (McCormack 2008) and policy frameworks (Chandler 2008), and the tendency of human security to strengthen international institutions rather than empowering individuals (McCormack 2008). Others have highlighted how this new paradigm has not brought any particularly innovative practical strategy or positive outcome in humanitarian operations (Muggah and Krause 2006), but rather has de facto replaced development aspirations and inscribed them into a security agenda (Pupavac 2005).

\section{Alice Massari}

\section{References}

Chandler, D. (2008) Review Essay: Human Security: The Dog That Didn't Bark. Security Dialogue, 39 (4): 427-438.

Grayson, K. (2004) A Challenge to the Power over Knowledge of Traditional Security Studies. Security Dialogue, 35(3): 357 .

MacFarlane, S.N. (2004.) A Useful Concept That Risks Losing Its Political Salience. Security Dialogue, 35(3): 368-369.

McCormack, T. (2008) Power and Agency in the Human Security Framework. Cambridge Review of International Affairs, 21(1): 113-128.

Muggah, R., Krause, K. (2006) A True Measure of Success-The Discourse and Practice of Human Security in Haiti. In: MacLean, S.J. et al. eds. A Decade of Human Security: Global Governance and New Multilateralisms. Routledge. 
Newman, E. (2001) Human Security and Constructivism. International Studies Perspectives, 2(3): 239-251.

Ogata, S., Sen, A. (2003) Final Report of the Commission on Human Security. United Nations Commission on Human Security.

Pupavac, V. (2005) Human Security and the Rise of Global Therapeutic Governance. Conflict, Security and Development, 5(2):161-181.

Suhrke, A. (1999) Human Security and the Interests of States. Security Dialogue, 30(3): 265-276.

Tadjbakhsh, S., Chenoy, A. (2007) Human Security: Concepts and Implications. Routledge.

UNDP (United Nations Development Program) (1994) Human Development Report. UNDP.

\section{Human Trafficking}

Trafficking in persons (TIP) is the recruitment, transportation, transfer, harboring, or receipt of persons, typically for, but not limited to, the purposes of sexual exploitation or forced labor (UNODC 2018). "Trafficking" is also described as a modern slave trade, a throwback to an ancient time that has its roots in precapitalist societies. Until recently, there was no international agreement on the legal definition of trafficking. In 2000, the United Nations (UN) Convention against Transnational Organized Crime and its accompanying protocols - more commonly known as the Palermo Protocols-were adopted by the UN General Assembly to clarify the term and distinguish the phenomenon from human smuggling. According to the UN, human trafficking involves "the threat or use of force or other forms of coercion, of abduction, of fraud, of deception, of the abuse of power or of a position of vulnerability or of the giving or receiving of payments or benefits to achieve the consent of a person having control over another person, for the purpose of exploitation. Exploitation shall include, at a minimum, the exploitation of the prostitution of others or other forms of sexual exploitation, forced labor or services, slavery or practices similar to slavery, servitude or the removal of organs. The consent of a victim of trafficking in persons to the intended exploitation ... shall be irrelevant where any of the means set forth ... have been used" (UN 2000: 42).

Nonetheless, in public discourse, TIP often continues to be confused with the smuggling of people ( $\mathrm{SOM}$ ), which is "the procurement, in order to obtain, 